\title{
COMPETENCE AND COOPERATION OF THE PUBLIC PROSECUTION OFFICE WITH THE MINISTRY OF INTERIOR OF THE REPUBLIC OF MACEDONIA
}

\author{
Sonja Aleksova \\ Faculty of Law at University "Goce Delchev"-Stip, Macedonia, \\ sonja_2010@live.com
}

Professional Paper doi:10.5937/jouproman5-13551

\begin{abstract}
The investigation on the public prosecutors of the Republic of Macedonia and its role and responsibility as well as its cooperation with the authorities is a particular challenge which requires serious approach. The european public prosecution is still reflecting two contrasting traditions, which are adversarial and inquisition proceedings. In the middle ages, in all european countries was known the competence of individuals and their power to initiate criminal proceedings, thus it suggests that there was a system of private prosecution. The public prosecution office is a specialized and specific state institution carrying out legal measures against people who have committed crime and other offences as stipulated by law. The public prosecution office represents a special state body which is independent from the judicial and executive powers.
\end{abstract}

Keywords: crime; criminal procedure; doubt; accusation.

\section{Introduction}

The public prosecution office as a separate institution exists in every modern criminal justice system, respectively this institution exists in countries belonging to the common law system (characterized by adversarial model of criminal proceedings), and countries belonging to the continental system - civil law (in which are represented mixed types of criminal proceedings).

The public prosecutor has a special role in the prosecution as an initiator, as well as an actor in criminal proceedings. The public prosecution office as a separate state body is a particularly interesting body because it is in a position to maintain a balance between its functioning as part of the system for protection of human rights on the one hand and as an initiator of deprivation or restriction of those same freedoms and rights in the criminal proceedings, on the other.

\section{Competence of the public prosecution of Macedonia}

The competences of public prosecutors in the Republic of Macedonia are regulated by the Law on public prosecution and the Law on criminal procedure. Namely, in the separate part three of the draft Law on the public prosecution are regulated the competences of the public prosecution and the public prosecutors. According to this law, the public prosecution has the authority to act within the limits of its material and territorial jurisdiction, which stipulates that (Law on the public prosecution office, 2007, article 29):

- Basic public prosecutors are competent to act in front of the basic courts,

- Higher public prosecutors are competent to act in front of the Appellate court,

- The public prosecutor's office for organized crime and corruption shall proceed before the basic courts with a specialized judicial department, in charge of adjudication of criminal offences in the area of organized crime. 
- The public prosecutor of Macedonia is competent to act in front of the Supreme court of Macedonia.

The public prosecution office of Macedonia, within the framework of the international agreements, shall establish direct cooperation with the public prosecution offices in other states, especially in the field of preventions and prosecutions of organized crime and other serious forms of crimes, through direct data exchange, specialization, cooperation, education etc. (Law on the public prosecution office, 2007, article 36).

According to article 30 paragraph 1 of the law on public prosecution of Macedonia, in the realization of his/her function of prosecution of perpetrators of crimes and misdemeanors, the public prosecutor have the following responsibilities and competencies:

- has the authorizations that also belong to the Ministry of the interior of Macedonia and another institutions for detection of crimes and their offenders and collection of evidence for the purpose of criminal prosecutions of the offenders of crimes;

- $\quad$ in the pre-investigative procedure, have an authority to issued orders for the undertaking special investigative measures;

- manage the pre-investigative procedure and dispose of the authorized officials from the ministry of interior, the customs administration and the financial police, pursuant to the law; ${ }^{1}$

- have the right to undertake independently any actions necessary to detect crime and detect and prosecute the perpetrators, for which, the law authorizes the ministry of interior, the

\footnotetext{
1 Retrieved from: http://justice.gov.mk/ ; Last visited: 20.03.2017.

2 Retrieved from: http://justice.gov.mk/ ; Last visited: 20.03.2017.

customs administration and the financial police of the Republic of Macedonia; ${ }^{2}$

- decides whether to undertake or continue with prosecution of the perpetrators of criminal offences;

- move and represent indictments before the courts;

- enunciate regular and extraordinary legal remedies against judicial decisions;

- file requests for initiation of misdemeanor proceedings; and

- undertake other actions prescribed by law.

If no actions are taken by the other state institutions referred to above, the public prosecutor on his own may undertake all the actions that are usually undertaken by authorized personnel from the Ministry of interior or other state institutions.

According to Article 31 of the law on public prosecution of Macedonia, the public prosecutor's office for organized crime and corruption has the following responsibilities:

- to act on "crimes that have been committed by a structured group of three or more people, which group exists for a certain period of time and acts in order to commit one or more criminal offenses for which is predicted a sentence of imprisonment of at least four years", with an intent to acquire financial or other gain, directly or indirectly;

- to act on "crimes that have been committed by a structured group or criminal organization in the territory of Macedonia or another states", or in instances when the crime was organized or planned in the Republic of Macedonia or another state; 
- to act for the following offenses: misuse of official position and authority, accepting bribes of a significant value and illegal mediation, which are crimes defined by the Criminal code and are carried out "by an elected or appointed functionary, official or responsible person in a legal person";

- and to act for the following offenses: unauthorized production and distribution of narcotic drugs, money laundering and another proceeds of some punishable acts of a greater value, terrorist endangerment of the constitutional order and security, giving bribes of a significant value, unlawful influence on witnesses, criminal enterprising, terrorist organizations, terrorism, crimes of human trafficking, crimes of smuggling of migrants, trafficking of juveniles and the rest of "the crimes against humanity and crimes against international law" stipulated by the Criminal code of Macedonia, irrespective of the number of criminals.

About issues of importance for the realization of the prosecutorial function, as well as for issues related to detection of criminal offences and criminals, the public prosecutor cooperate and coordinate its activities with all other state institutions and legal entities (Law on the public prosecution office, 2007, article 32).

In terms of the authorization that the public prosecutor of Macedonia has directly in front of the Constitutional court of Macedonia, it is noted that this authorization consists of submitting an initiative for initiating a procedure for assessing the conformity of a law or other regulations with the Constitution and laws. It is characteristic that this power can be achieved only when in the work of the public prosecutor it is asked a question about the constitutionality and legality. The public prosecutor of Macedonia shall be informed on issues of constitutionality and legality in the work of basic public prosecutions, the public prosecutor's office for organized crime and corruption and higher public prosecutor's offices.

The public prosecutor has the authority to receive complaints, petitions and other submissions and statements from citizens of other bodies and other legal entities, but only for activities and tasks within the competence of the prosecutor, as well as taking actions in which the public prosecutor is authorized. Once the prosecutor receives a criminal charge, it is his/her duty to take an action which has the legal authority for it and should act as soon as possible, but not more than 30 days after the criminal application (Law on the public prosecution office, 2007, article 37).

In accordance with the law, in some cases there is a possibility the prosecutors of the Republic of Macedonia to prosecute and perform certain matters that normally are performed by higher public prosecutors or basic public prosecutors for prosecutions of organized crimes and corruptions, respectively there is an opportunity for the public prosecutor of Macedonia to empower them (higher, basic or basic prosecutors with competence for prosecution of organized crime and corruption) to perform tasks within the competence of another prosecutors in the Republic of Macedonia or to link a specific procedure in certain cases.

With the new law on criminal procedure of Macedonia (Law on the criminal procedure, 2010) of crimes prosecuted ex officio, the public prosecutor of Macedonia coordinate and manage the work of the officials from the Ministry of interior of Macedonia and another institutions with competence, in undertaking the required measures needed to find the offender of the crime. 
The public prosecutors in the Republic of Macedonia are entrusted overall with the pre-trial and investigative procedure in which the prosecutors have the right and duty to the following (Law on the criminal procedure, 2010, article 39):

- "to submit and represent charges before the competent court";

- "innovate, propose and provide evidence";

- "to direct the actions of the authorities responsible for detection and reporting of crimes and their perpetrators",3;

- "to decide to postpone the criminal prosecution";

- "to propose a penal warrant".

- "to propose / issue orders for taking special investigative measures, to conduct an investigation procedure and temporary measures for safeguarding property or items gained through a criminal act or for the execution of the measure confiscation",

- "to negotiate and to agree with the defendants to plead guilty";

- "to file appeals against court decisions and extraordinary remedies against final court decisions";

- "to decide on a complaint of the injured party".

Public prosecutors in civil and other legal proceedings, as well as in administrative proceedings, have the competence to take legal actions for which they have legal authority. The Law on criminal procedure in article 43 suggests that in agreement with the injured party, the "public prosecutor with the consent of the victim with an appropriate decision to postpone the prosecution for a criminal offense which is punishable with imprisonment up to three years" if the

\footnotetext{
3 Retrieved from: http://justice.gov.mk/ ; Last visited: 20.03.2017.

${ }^{4}$ Retrieved from: http://justice.gov.mk/ ; Last visited: 20.03.2017.

5 Retrieved from: http://justice.gov.mk/ ; Last visited: 20.03.2017.

suspect is willing to act on the instructions of the public prosecutor and to meet specified obligations that reduce or remove harmful consequences of the crime, put an end to the disturbance resulting from the offense, in order the suspect to reintegrate.

Article 44 of the criminal code of Macedonia determines the cases in which the public prosecutor is obliged to prosecute or may withdraw from the prosecution, in the following cases:

- If the Criminal Code states that "the court may release the perpetrator of a crime from punishment if the public prosecutor, considering the specific circumstances of the case finds that a judgment without sanction is not required";

- If the criminal code "prescribes a fine or imprisonment up to three years for the offense, and the perpetrator's repentance prevented the damaging consequences or compensated the damage and if the public prosecutor, considering the specific circumstances of the case, finds whether the criminal sanction is established on solid grounds" $"$.

- If "he suspect as a member of an organized group, gang or other criminal association voluntarily cooperates before or after or during the criminal proceedings and if such cooperation and statement of that person is crucial for the criminal proceedings". ${ }^{8}$

\footnotetext{
${ }^{6}$ OSCE, Criminal Procedure Law, Official gazette No. $150 / 2010$ - Unofficial translation in English. Article 44/1. Retrieved from: http://www.ecoi.net/file_upload/1226_1371805030_fyrom -cpc-am2010-en.pdf; Last visited: 23.03.2017.

OSCE, Criminal Procedure Law, Official gazette No. $150 / 2010$ - Unofficial translation in English. Article 44/2. Retrieved from:

http://www.ecoi.net/file upload/1226 1371805030 fyrom -cpc-am2010-en.pdf; Last visited: 23.03.2017.

${ }^{8}$ OSCE, Criminal Procedure Law, Official gazette No. $150 / 2010$ - Unofficial translation in English. Article 44/3. Retrieved from: http://www.ecoi.net/file_upload/1226_1371805030_fyrom -cpc-am2010-en.pdf; Last visited: 23.03.2017.
} 


\subsection{Cooperation of the public prosecution office of the Republic of Macedonia with the Ministry of interior of the Republic of Macedonia}

There is an emphasized cooperation between the public prosecution of Macedonia and the Ministry of interior on the same country, especially in terms of detection of crimes and their perpetrators. There are different opinions about the relations between the Ministry of interior of Macedonia and the public prosecution of the Republic of Macedonia.

According to the first opinion, it is considered that the public prosecution and the Ministry of interior represent equal bodies and therefore none of these bodies must be placed above the other.

According to the second opinion, it is considered that the Ministry of interior has autonomy only within the limits of its competence.

According to the third opinion, it is considered that the Ministry of interior shall be helpful to the public prosecution throughout the proceedings, even after the filing of criminal charges. It is considered particularly difficult to define this complex relationship. The law on criminal procedure defines the rights and obligations of these authorities and in compliance with the legal actions of the Ministry of interior of Macedonia are divided in three groups of tasks, such as:

- The tasks of the Ministry of interior in pretrial detection of crimes and perpetrators;

- The tasks for the enforcement of the powers from the Ministry of interior of Macedonia in the criminal proceedings;

- The tasks of helping the court to the successful implementation of the criminal procedure;
The relationship between the public prosecution of Macedonia and the Ministry of interior of Macedonia is the most important in the pretrial procedure, because the most important activity of this procedure is the detection of crimes and their perpetrators whereas the Ministry of interior in accordance with its function, executes a big part of the actions in this procedure.

The public prosecutor has the authority to take independently the actions carried out from the officials in the Ministry of interior of Macedonia who are authorized or another government bodies, but only when there is a failure of these state bodies. For crimes that are prosecuted ex officio, the public prosecutors coordinate and manage the work on the officials who are authorized from the Ministry of interior of Macedonia and another competent institutions, in undertaking the required measures needed to find the person who committed crime, to prevent the offender and the accomplice in crime from hiding, to discover or provide the traces and indicators of the crime act, also the articles that might serve as proof.

The law on public prosecution stipulates that the Ministry of interior and other state bodies must notify the public prosecutor about all actions that have been taken in pre-trial proceedings for crimes for which the public prosecutor is responsible for prosecution of perpetrators of crimes in the field of organized crime and corruption. 
The Ministry of interior of Macedonia, the Financial police of the Republic of Macedonia and the Customs administration of the Republic of Macedonia, at the moment of filing charges, has a duty promptly hand over to the public prosecutor all documents, evidence material, as well as all the information they acquired during the discovery of all criminal offences and their perpetrators.

All records, documents, information and items that are needed shall be submitted to the public prosecutor and their delivery is a duty of the state authorities, authorities of the local self-government and legal and natural people exercising public powers. ${ }^{9}$

If there is a thought that certain legal entities and citizens dispose of certain information and data, in this case the public prosecutor in the exercise of its jurisdiction has the right to issue an order to be delivered to such data and information.

In exercising his or her competencies, the public prosecutor may consult with and collect opinions from experts in certain fields, which are necessary in order for him or her to reach a decision. The Ministry of interior of Macedonia and other state bodies and people are obliged to take all necessary measures, as soon as possible, but not exceeding 30 days, to provide the requested informations, documents and case files to the public prosecutors.

If institutions and people fail to deliver the information and reports, documents, case files, papers and bank statements requested by the public prosecutors, they have the right to procure those and get an insight, and about the no delivery, the public prosecutors shall inform the Minister of interior of Macedonia or other officials in state institutions of the Republic of Macedonia, for who was addressed the request, also the public prosecutors may also initiate some actions for criminal or disciplinary responsibility as stipulated by the law. The insight into banking accounts shall not constitute a bank secret violation (Law on the public prosecution office, 2007, article 33). Under article 34 of the law on public prosecution, the public prosecutor may order that one or more specifically identified officials from the Ministry of interior of Macedonia, who are authorized and another state institutions of the Republic of Macedonia to be awarded at disposal for a fixed period, both in the preliminary and the criminal proceedings taken on his request, in performing the prosecution of organized crime, corruption and another crime that includes a minimum imprisonment of four years or when that is required because of special circumstances.

The authorized official from the Ministry of interior and other state institutions of Macedonia, act according to the instructions and orders which are given by prosecutors of Macedonia. The authorized official may not be recalled from the duties performed without the consent of the public prosecutor.

The office of public prosecution of Macedonia take care about the legality of measures and actions taken during the preinvestigative procedure and conduct an oversight of the observance of human rights by the officials by the Ministry of interior of Macedonia and other institutions who have an authority. If the public prosecutor receives information that some officials by the Ministry of interior of Macedonia and another institutions have exceeded their authority and wounded the freedoms and rights of the citizens, the public prosecutors have right to immediately be informed if a procedure for establishing liability has been initiated against these people or not, as well as about the progress, i.e. the result from the completed procedure.

\footnotetext{
9 Retrieved from: http://justice.gov.mk/ ; Last visited: 20.03.2017. 
The public prosecutors, ex officio, shall initiate a procedure for establishing liability to determine the justification and reasons for the using weapons from the officials by the Ministry of interior of Macedonia and other institutions who have such an authority as provided by the law, if such use has death or a serious bodily injury as a consequence. The public prosecutor shall have an insight and access to all the evidence and papers in the appropriate department, on the basis of which the assessment of the justification for the use of firearms has been made (Law on the public prosecution office, 2007, article 35).

\section{Conclusion}

It can be concluded what are the responsibilities and competencies of the public prosecutor in exercising his/her function of prosecuting perpetrators of crimes and misdemeanors. The office of public prosecution in Macedonia, within the framework of the international agreements, shall establish direct cooperation with the public prosecution office from different states, especially in terms of prosecuting and prevention of crime.

According to the new law on criminal procedure, general right and duty of the public prosecutors of Macedonia is to prosecute criminals for crimes prosecuted ex officio. This law provides different solutions from the previous law, in relation to the work of the public prosecution, i.e. in the new law on criminal procedure, public prosecutors are entrusted with the overall pre-investigative and criminal procedure. There is an emphasized cooperation between the public prosecution and the Ministry of interior especially in terms of detecting criminal acts and their perpetrators.

In conclusion, the essentials is the relationship between the public prosecution and the Ministry of interior of Macedonia in the pre-trial procedure, because the most important activity of this procedure is the detection of crimes and their perpetrators whereas the Ministry of interior in accordance with its function, executes a big part of the actions in this procedure.

\section{References:}

[1] Matovski, N.; Buzarovska - Lazhetikj, G.; Kalajdziev, G. (2011). Law on Criminal Procedure. Faculty of Law "Justinian I" Skopje.

[2] Buzarovska G. (2007). Redefined role of the public prosecutor in criminal proceedings. Faculty of Law "Justinian I" Skopje.

[3] Velkovski V. (1996). Constitutional position of the public prosecution. Judicial Review No. 5, Skopje.

[4] Law on the public prosecution office, Official Gazette of the Republic of Macedonia No. $150 / 2007$

[5] Law on criminal procedure, Official Gazette of the Republic of Macedonia no. 150/18.11.2010.

[6] Constitution of the Republic of Macedonia, Official Gazette of the Republic of Macedonia No.52/92.

[7] Constitutional amendment XXX, Official Gazette of the Republic of Macedonia no.107/05.

[8] Public prosecutor of the Republic of Macedonia. Available on: http://jorm.gov.mk/?page_id=11, 20.03.2017.

[9] OSCE, Criminal Procedure Law, Official gazette No. $150 / 2010$ - Unofficial translation in English. Article 44.

[10] Retrieved from: http://www.ecoi.net/file_upload/1226_1371805 030_fyrom-cpc-am2010-en.pdf; Last visited: 23.03.2017.

[11] Retrieved from:http://www.track.unodc.org/LegalLibrary/ pages/LegalResources.aspx?country=Macedoni a; Last visited: 20.03.2017.

[12] Retrieved from: http://justice.gov.mk/; Last visited: 20.03 .2017 